\title{
Review of The Evil Axis of Finance: The US-Japan-China Stranglehold on the Global Future
}

\author{
WILLIAM CARROLL \\ University of Victoria, Canada
}

The Evil Axis of Finance: The US-Japan-China Stranglehold on the Global Future.

Written by Richard Westra, Atlanta, GA: Clarity Press, (2012)

ISBN: 9780932863904

This provocatively titled study takes up a topic, international finance, whose opacity often induces a trance-like state in readers. Written in an engaging, even breezy style, Westra's book follows in the tradition of Marx's Capital, as both a critical analysis of the contemporary capitalist system and a critique of the liberal economic theories that make that system appear rational and inevitable. The book is intended for an educated, non-specialist readership, including undergraduate students in the social sciences and related fields, as well as progressive policy makers and activists. It presents a cogent analysis of the long-term underpinnings of the 2008 global financial meltdown and the emergent form of capitalism whose logic became acutely visible in the subsequent fallout. Westra holds that the US, Japan and China have come to form an "evil axis" of finance that places a stranglehold on the world's future. In this post-imperialist scenario, Wall Street comprises the "new command center from which the US, supported by evil axis partner dollar holdings, manages the world economy by 'remote control' for its own selfaggrandizement," with Japan, China, the EU and select other states "feeding at the trough" (p. 20).

The axis is evil - a moral judgment upon which Westra insists - for two main reasons. On the one hand, it portends a retrograde mode of accumulation: capitalism's progressive mission is long past. With the hypertrophy of financial 
capital into derivatives, hedge funds, bundled assets and the like, productive capital is disarticulated and decays as a source of employment and revenue, particularly in the US but also more generally. With the eclipse of productioncentered capitalism, enormous quantities of idle money metastasize into an "evil force" that resembles ancient usury-extracting its "pound of flesh" from whosoever falls into its clutches, whether the people of Greece or the millions suffering under a global agricultural regime in which food prices are set by speculative churning on derivatives markets. Capitalism's increasingly retrograde character is also visible in the shift of productive capital to places like China, whose brutal authoritarian regime subtends "dark modes of labor control [underwritten by a massive, elastic supply of displaced rural workers] that in part hark back to bondage-like work forms existing at the dawn of the capitalist era" (p. 146). On the other hand, the axis is evil in its indifference to the impending food, energy and climate change crises. In Westra's view, global ecological crisis "is likely to be the foundation for the final economic bubble" as Wall Street gorges itself "before the deluge" (p. 208).

The core of Westra's historical analysis is a nuanced account of how the "golden age" of post-war fordist consumer-capitalism morphed into the contemporary degenerate form. In the 1980s, as US global industrial dominance visibly eroded (the result of offshoring and insourcing practices of US TNCs in search of cheap labour), the US parlayed its unique position as issuer of world currency into a "substitute source of global supremacy" (p. 74). The new accumulation regime retains the ideology of consumerism so central to the golden age, even as four-fifths of Americans are Walmartized while the top fifth of enjoys the lifestyle of overconsumptionism, fueled by imports of high-end goods. Indeed, it is only by running massive deficitstrade, budget, capital account, near-zero savings - that the US economy is able to register "growth": the asset bubbles and rotating meltdowns which now constitute "the surrogate US economy" of speculative casino capitalism (p. 142). Within the evil axis of finance, surplus earnings from industrial production in Japan and especially China are funneled into the US Treasury bill purchases that keep the dollar afloat, with the entire system of investment and trade relations "guaranteeing the malignancies of each economy [American hyperconsumptionism, Chinese authoritarian labour control] will spread to infect the world" (p. 146).

Westra sees no hope of rescue via conventional political and economic practices. In the wake of the 2008 collapse, State largesse to US and European banks has created a "doom loop" as socialized bank losses encourage more reckless risk-taking, setting the table for the next meltdown. The remedy he offers in conclusion-rejuvenation of local economies under democratic community control - seems to apply specifically to the US, whose political left has for decades been in a deep abeyance that limits possibilities for transformative change beyond the local level. This is consistent with the book's focus on Wall Street/Washington as the evil axis's ground zero, but it may underestimate the potential of social forces located elsewhere, as in Latin America's "pink tide," with its alternative regionalism (including 
the Bank of the South) and its emphasis upon participatory democracy and food sovereignty. This pessimistically realistic book's strength lies in laying bare the deeply dysfunctional logic of capitalism in the early $21^{\text {st }}$ Century. Scholars and activists interested in social justice will have to draw their own place-specific practical conclusions. 